Vol. 11 (2002): 3-11.

\title{
Optimal beef cattle management under agricultural policy reforms in Finland
}

Pekka Pihamaa and Kyösti Pietola

MTT Agrifood Research Finland, Economic Research, PO Box 3, FIN-00411 Helsinki, Finland, e-mail: pekka.pihamaa@mtt.fi

The supply for domestic beef has been decreasing sharply since Finland joined the European Union (EU) because profitability of beef production has been low. The goal of this study is to search for optimal beef management practices that increase returns on beef production in Finland. Numerical dynamic programming (DP) is used to simultaneously optimise feeding and timing of slaughtering. The DP-algorithm is solved under alternative subsidy, output price, and silage price scenarios. At 1998 prices and subsidies, the optimal carcass weight is estimated above $250 \mathrm{~kg}$. The European

Agenda 2000 reform is predicted to decrease the optimal carcass weight to $200 \mathrm{~kg}$, which is $50 \mathrm{~kg}$ lower than under the 1998 prices and subsidies. This reform will increase farmer returns significantly and its income effect depends crucially on the price of silage. The results indicate also that the reform will result in adjustment of feeding. Particularly, farmers having high silage production costs will substitute feed concentrates for roughage in the diet.

A farmer is entitled to a premium subsidy of FIM 200 (€33.63), provided that the carcass weight of a culled animal exceeds $270 \mathrm{~kg}$. But when the Agenda 2000 reform is fully implemented, this premium subsidy is not large enough to supply carcasses heavier than $270 \mathrm{~kg}$. The results suggest that carcass weights of at least $270 \mathrm{~kg}$ would require a premium subsidy of FIM 400-800 (€67$€ 134)$. Rearing heavy animals will significantly increase production costs and, therefore, most of the subsidy will be taken away from the farm in terms of increased costs.

Key words: beef cattle, diet, dynamic programming, subsidies

\section{Introduction}

European agricultural policy reforms have resulted, and are further expected to result, in large changes in the beef sector. Particularly, in a high cost country such as Finland, these reforms have important implications for the economics of the beef sector and for farmer incentives to rear cattle. The combined effects of decreasing producer beef prices and gradually increasing forage costs have been considerable at weakening the supply for domestic beef. During the first years in which Finland has been in the European Union (EU), beef producers have had difficulty attaining profitability and more than $7 \%$ annually

(C) Agricultural and Food Science in Finland

Manuscript received May 2001 
Pihamaa, P. \& Pietola, K. Optimal beef cattle management in Finland

have quit cattle operations (TIKE 2000a). Beef production has been decreasing by $3 \%$ annually (TIKE 2000b). Therefore, the traditional experience of excess supply has quickly turned into a deficiency of domestic beef. It is expected that without new domestic programs encouraging beef production the supply for beef will be further weakened. The Agenda 2000 reform, for example, has a goal of decreasing beef production in Europe and this reform is expected to have similar effects in Finland.

Enhancing domestic beef production is an important policy goal in Finland. To promote domestic beef production, the Finnish government has designed domestic subsidy programs which complement the European common programs in supporting cattle farmers. These subsidies can be characterized as direct income subsidies but they also have links so as to increase farmer incentives in rearing heavier animals. Thus, these income subsidies have a goal of increasing farmer income and strengthening the supply for beef.

The performance of the subsidy programs combined with low beef prices and high forage production costs raises at least two important questions. The first question is how efficient these subsidies are in increasing farmer income if the subsidies are not fully decoupled from production. The subsidy rates increase with the weight of the culled animal. The second question is how much these subsidy schemes affect optimal beef production management and the supply of beef.

The goal of this paper is to simulate optimal cattle management solutions under alternative policy, price, and forage cost scenarios. Policy scenarios include the Agenda 2000 reform and the domestic subsidy schemes in which the subsidy rates are linked to certain carcass weights of the culled animals. Forage cost scenarios reflect alternative (farmer specific) planning situations and horizons. In the short run model, forage production costs include only variable costs whereas the long run model includes all forage production costs.

The dynamic optimization model is con- structed in an optimal stopping framework solving the optimal decision rules numerically using the Bellman's principle of optimality and recursive Dynamic Programming (DP) (Bellman 1957). A numerical solution technique is used because the optimal feeding and optimal timing of slaughtering cannot be solved analytically in closed form. The numerical approach also has an advantage in simulating the effects of animal weight thresholds that trigger certain lump sum subsidy payments. In addition, dynamic programming is generally considered to be the preferred technique for modeling optimal animal management problems (e.g. Glen 1983, Van Arendonk 1985, Boland et al. 1993, Huirne et al. 1993). In spite of its superiority, DP has not been applied to cattle management under Finnish production and market environment using animal breeding qualities that are common in Finland.

The outline of the paper is as follows. Subsequent sections present the economic model and the dynamic programming approach used in solving the optimal decision rules. The section, thereafter, presents data on the feeding experiment, prices, and subsidy rates. The two last sections give the results and conclude the paper.

\section{The dynamic programming model}

The goal of farmers is to maximize the discounted net present value $\left(V_{t}\right)$ of beef bull production by choosing optimal animal feeding $\left(u_{t}^{f}\right)$ and timing of slaughtering $\left(u_{t}^{s}\right)$. The optimization problem has a recursive structure such that it obeys the Bellman equation (Bellman 1957) of the form

$$
V_{t}\left(x_{t}\right)=\max _{u^{s}, u^{f}}\left\{R_{t}\left(x_{t}, u_{t}^{s}, u_{t}^{f}\right)+\beta V_{t+1}\left(x_{t+1}\right)\right\}
$$

subject to

$$
\begin{aligned}
x_{t+1}= & x_{t}+f\left(x_{t}, u_{t}^{f}\right) \text { if } u_{t}^{s}=0 \text { (continue to } \\
& \text { grow) and } \\
x_{t+1}= & x_{0} \text { if } u_{t}^{s}=1 \text { (slaughter) } .
\end{aligned}
$$

$x_{t}$ is the live weight of the animal (also referred to as animal weight), $R_{t}$ is the one period return, 
Vol. 11 (2002): 3-11.

$\beta$ is the exogenous discount factor and it corresponds to the annual interest rate of $8 \%$. The subscript $t$ refers to time. In the transition equations, $f($.) determines animal growth, provided the animal is not slaughtered. $x_{0}$ is the live weight of the new calf that is replaced for the slaughtered animal.

In a Nordic production environment, the standard is that cattle are raised indoors for most of the time and the matured animal has to be culled before the stable can have space for a new calf. Therefore, the optimal value function $\left(V_{t}\right)$ and the one period return function $\left(R_{t}\right)$ are standardized per unit of capacity to grow one animal. Stacking the continuation and stopping regions together, the one period return function takes the form

$$
\begin{aligned}
& R\left(x_{t}, u_{t}^{s}, u_{t}^{f}\right)=\left(1-u_{t}^{s}\right)\left[-C\left(u_{t}^{f}, x_{t}\right)+S_{t}^{C A P}\left(x_{t}\right)\right. \\
& \left.+S_{t}^{N A T}\left(x_{t}\right)\right]+u_{t}^{s}\left[L P_{t}^{m} x_{t}+S_{t}^{s}-P_{t}^{C}\right]
\end{aligned}
$$

where $C\left(u_{t}^{f}, x_{t}\right)$ is the feed cost, $S_{t}^{C A P}$ is the Common Agricultural Policy (CAP) subsidy, and $S_{t}^{N A T}$ is the domestic (national) subsidy. CAP and domestic subsidy rates are a function of animal weight. The parameter $L$ is the percentage of carcass weight from the animal weight. $P_{t}^{m}$ is the producer price for meat, $S_{t}^{S}$ is the lump sum subsidy paid per animal when it is slaughtered, and $P_{t}^{C}$ is the price of the calf. The calf price includes all transaction costs of animal replacement.

The one period function includes two parts: returns over the continuation region and returns upon stopping. In the continuation region we have $u_{t}^{s}=0$ implying that the returns (or costs) are the feeding costs and the realized subsidy rates depending on the current weight of the animal. Over this region, the next period weight is controlled by optimal feeding $\left(u_{t}^{f}\right)$ through the animal growth function $f$. When it is optimal to cull the animal, we have $u_{t}^{s}=1$ and the farmer receives the returns from slaughtering, subtracted by the price of a new calf.

At the end of the planning horizon (at $t=T$ ), the animal is always culled and the terminal value function is

$$
V_{T}\left(X_{T}\right)=L P_{T}^{m} X_{T}+S_{T}^{S}
$$

\section{The data}

\section{Animal growth and feed uptake}

The data are cattle feeding experiments carried out by Agricultural Research Centre of Finland (nowadays MTT Agrifood Research Finland) in 1995-1996 (Rinne et al. 1998, Nissi and Pietola 1999). The experiments included 16 Ayrshire bulls with an average initial live weight of $94 \mathrm{~kg}$ at an initial age of 82 days. Two different feeding ratios were applied. Barley was the main concentrate and silage the main roughage of the diet in the experiment. For the first block of animals, the concentrate was given at a rate of $50 \mathrm{~g}$ $\mathrm{DM} \mathrm{kg}^{-1} \mathrm{LW}^{0.6}$ (where DM is the amount of dry matter and LW is live weight) and for the second group of animals, the concentrate was given at a rate of $100 \mathrm{~g} \mathrm{DM} \mathrm{kg}^{-1} \mathrm{LW}^{0.6}$. Grass silage was given ad libitum. These feeds were supplemented by a necessary amount of minerals. Bulls also received some rape seed during the first four months of the experiment.

Feed ratios varied in a moderate range and no significant path dependency was observed (Nissi and Pietola 1999). Therefore, the animal growth satisfies the Markov property such that the current state (e.g. live weight) and feeding determines the animal growth. Path dependency is also referred to as compensatory growth such that if a period of poor feeding is followed by rich feeding the animal will grow faster than applying constantly the rich feeding.

Animal growth and the demand for barley and silage were estimated by the standard Ordinary Least Squares (OLS) method. As suggested by the biological theory on animal growth, an exponential Gompertz-function was fitted in the data. The live weight gain was estimated separately for both feeding groups.

The demand of silage was estimated as a nondecreasing logarithmic function of live weight. Maintenance requirements are expected to increase with animal weight such that the demand for silage never decreases when live weight increases. The demand for barley was estimated 


\section{Pihamaa, P. \& Pietola, K. Optimal beef cattle management in Finland}

as a power function of live weight. The estimated animal growth and feed demand functions and the observed data points are presented in Appendix 1.

The length of the planning horizon $(T)$ was set at 2,282 days, which corresponds to about 6 years and 3 months. The length of the single time period (the node in the DP algorithm) is 7 days and the state space for live weight is any integer between 94 and $600 \mathrm{~kg}$. The initial weight of $94 \mathrm{~kg}$ is based on the average weight of the calves when they entered the experiment.

\section{Prices and subsidy rates}

The prices for meat, calves, barley, rape seed, and minerals are average market prices in 1998 and their expected prices in the year 2002. The price expectations in year 2002 are based on future intervention prices. The price of silage is based on its production costs, as they are estimated in the enterprise budgets of agricultural extension services (named as HILA-accounts). Three alternative silage prices are simulated. These prices are denoted later as "high," "medium," and "low" prices of silage. The high price is the average production cost of silage in the HILA-accounts. This cost reflects the long run planning horizon when all costs have to be taken into an account, or, alternatively, producers who buy the harvest service from a contractor who is assumed to charge average production costs of harvesting the silage. Total production cost is $60 \%$ higher than the medium price which

Table 1. Input prices in 1998 and 2002.

\begin{tabular}{lccc}
\hline & Unit & 1998 & 2002 \\
\hline Barley & FIM/kgDM & 0.92 & 0.78 \\
Silage & & & \\
low & FIM/kgDM & 0.66 & 0.70 \\
medium & FIM/kgDM & 0.82 & 0.88 \\
high & FIM/kgDM & 1.31 & 1.39 \\
Rape seed & FIM/kg & 1.94 & 1.94 \\
Minerals & FIM/kg & 2.75 & 2.75 \\
Calf & FIM & 1,448 & 1,208 \\
\hline
\end{tabular}

equals average variable cost and reflects the short run planning horizon. The low price is $20 \%$ lower than the average short run cost in HILA-accounts. This price reflects the short run planning situation on farms which show better than average economic performance. The low price is also justified in situations when farmers have excess silage inventories. The nominal production costs of silage are assumed to increase annually by $2 \%$ during the years 1998-2002. The prices of silage and other inputs are given in Table 1 .

The optimal decision rules are solved under alternative beef prices and under three policy scenarios. The first policy scenario is based on prices and subsidies observed in 1998. The second scenario mimics the Agenda 2000 reform and it is based on expected prices and subsidies in 2002. The third scenario uses the expected prices in 2002 but it adds a premium subsidy for heavier animals (paid at slaughtering). The premium subsidy is determined such that it is large enough for enhancing domestic beef production by supplying heavier animals in the market. The goal of the third simulation is to get information on how animal subsidies could be used in strengthening the supply for domestic beef and how efficient they are in increasing farmer income.

The Agenda reform is expected to decrease the intervention price of beef by $20 \%$ between 1998 and 2002 (Table 2). These market price

Table 2. Meat price (FIM/kg) by carcass weight in 1998 and 2002.

\begin{tabular}{lcc}
\hline Carcass weight & $1998^{*}$ & $2002 * *$ \\
\hline Under $189 \mathrm{~kg}$ & 13.30 & \\
$190-249 \mathrm{~kg}$ & 13.90 & \\
$250-299 \mathrm{~kg}$ & 15.30 & \\
Over $300 \mathrm{~kg}$ & 15.80 & 11.80 \\
& & 12.40 \\
Under $189 \mathrm{~kg}$ & 13.20 \\
$190-229 \mathrm{~kg}$ & 14.00 \\
$230-259 \mathrm{~kg}$ & 14.50 \\
$260-299 \mathrm{~kg}$ & & \\
Over $300 \mathrm{~kg}$ & & \\
\hline & & \\
* Source: TIKE 1999 and Maaseudun Tulevaisuus 1998. \\
** Source: TIKE 2001 and personal note from Lihakunta.
\end{tabular}


Vol. 11 (2002): 3-11.

Table 3. Subsidy rates for beef production in 1998 and 2002.

\begin{tabular}{llrr}
\hline & Unit & 1998 & 2002 \\
\hline CAP subsidy* & FIM/animal & 814 & 1,188 \\
CAP subsidy* & & & 475 \\
Northern subsidy & FIM/ LU/year** & 1,600 & 2,500 \\
Northern subsidy & FIM/animal/day & 2.63 & 4.11 \\
Transitional aid: & FIM/animal & 388 & 793 \\
$\quad$ Carcass weight $180-219.9 \mathrm{~kg}$ & FIM/animal & - & 200 \\
$\quad$ Carcass weight $\geq 220 \mathrm{~kg}$ & FIM/animal & &
\end{tabular}

* CAP subsidy was paid in 1998 for bulls older than 8 months and will be paid in 2002 at the time of slaughter for bulls heavier than $185 \mathrm{~kg}$ carcass weight.

** LU $=$ Livestock unit. A bull older than six months equals 0.6 livestock unit.

movements follow the decreasing intervention price for meat. The price of meat is adjusted by quality according to the quality adjustment schedules observed in 1998. The expected prices and subsidies of 2002 were simulated using the quality adjustment schedules observed in 2001.

Subsidy rates are set in the model as they are paid to a beef producer, located in Central Finland (subsidy area C2). In 1999, for example, more than $40 \%$ of domestic beef was produced in this area (TIKE 2000c). The results also generalize other most important beef production areas in Finland.

Beef producers receive national subsidies and subsidies included in the Common Agricultural Policy (CAP) of the EU. National Northern aid is paid annually for every bull that is older than six months. The national transitional aid was paid for slaughtered bulls in 1998 but the subsidy was cancelled in 1999 and will not be paid in 2002 (MMM 1998). This subsidy was the highest for bulls over $220 \mathrm{~kg}$ carcass weight.

The Agenda reform is expected to increase the CAP subsidy such that it will be more than $40 \%$ higher in 2002 than in 1998 . Also the payment schedule will be delayed. In 1998 the subsidy was paid according to the live animals on the farm but in 2002 farmers receive the payment after the animal is slaughtered. The minimum carcass weight required for the subsidy is $185 \mathrm{~kg}$. Also, a new CAP subsidy for slaugh- tered bulls was introduced with Agenda 2000 reform (EU 2000b). The complete set of subsidy rates in 1998 and their expected values in 2002 are given in Table 3.

The third policy simulation is to solve the DP algorithm under the expected prices for 2002 including increased premium subsidies for heavier animals. The subsidy rate is determined for having an optimal carcass weight of at least $270 \mathrm{~kg}$.

\section{Results}

\section{Decision rules and value functions at 1998 prices and subsidies}

At 1998 prices and subsidies, the optimal timing of slaughtering was estimated at 14.4 months when the carcass weight exceeds $250 \mathrm{~kg}$. The 250 kilogram weight hits the quality adjustment threshold such that the meat price was higher for carcasses exceeding $250 \mathrm{~kg}$ than for carcasses below the $250 \mathrm{~kg}$ (Fig. 1, Table 4).

The price of silage does not significantly affect the optimal timing of slaughtering but it affects farmer returns and animal feeding. When the price of silage is decreased by $20 \%$, from medium to low, the feeding remains practically unchanged but farmer returns increase by $10 \%$. 
Pihamaa, P. \& Pietola, K. Optimal beef cattle management in Finland

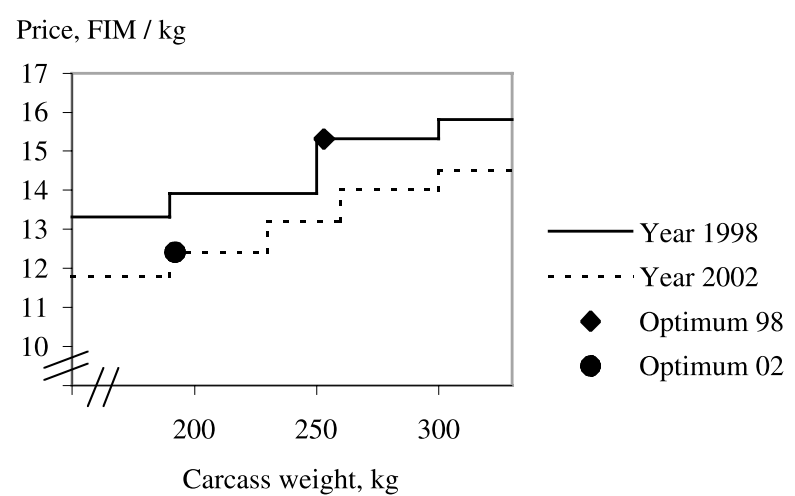

Fig. 1. Meat price thresholds and the optimal carcass weights in 1998 and 2002.

Table 4. Optimal decisions rules and value functions at 1998 prices and subsidy rates.

\begin{tabular}{llccc}
\hline & & \multicolumn{3}{c}{ Silage price } \\
\cline { 3 - 5 } & & Low & Medium & High \\
\hline Carcass weight at slaughter & $\mathrm{kg}$ & 255 & 255 & 253 \\
Age at slaughter & months & 14.9 & 14.9 & 14.4 \\
Value function & FIM & 13,145 & 11,803 & 8,177 \\
Concentrate/roughage ratio & $\%$ DM* & $24 / 76$ & $24 / 76$ & $35 / 65$ \\
\hline
\end{tabular}

* The $\%$-share of concentrate over the $\%$-share of silage in total amount of dry matter in the diet.

If the silage price is increased from medium to high, concentrates substitute for a substantial amount of silage in animal feeding and farmer returns are decreased by $30 \%$ (Table 4 ).

\section{Decision rules and value functions at 2002 prices and subsidies}

At 2002 prices and subsidies, the optimal timing of slaughter was estimated at 10.9 months of age and at a carcass weight of $194 \mathrm{~kg}$. Now, the optimal timing of slaughter is at the point were the bull reaches the first quality adjustment (price increase) after reaching the minimum weight required for the CAP subsidy (Fig. 1, Table 5). Thus, the Agenda 2000 reform is predicted to decrease farmer incentives to raise heavier animals, which will result in a weakened supply of beef given a fixed number of calves available for production.

The reform will, nevertheless, increase farmer returns by FIM 2,330-3,650 (€392-€615) per capacity unit over the planning horizon. In annual terms, the corresponding increase is FIM 372-584 (€62.7-€98.3) per capacity unit. The returns are predicted to increase the most for farmers paying high prices for silage. Substantial adjustment in animal feeding will also be realized. Particularly, farmers producing silage at the medium price will substitute more concentrates for silage than before the reform (Tables 4 and 5).

\section{Decision rules and value functions at 2002 prices and premium subsidies}

In this scenario, the size of the premium subsidy 
Vol. 11 (2002): 3-11.

Table 5. Optimal decision rules and value functions at 2002 prices and subsidy rates.

\begin{tabular}{llccc}
\hline & & \multicolumn{3}{c}{ Silage price } \\
\cline { 3 - 5 } & & Low & Medium & High \\
\hline Carcass weight at slaughter & $\mathrm{kg}$ & 191 & 191 & 194 \\
Age at slaughter & months & 10.9 & 10.9 & 10.9 \\
Value function & FIM & 15,475 & 14,289 & 11,828 \\
Concentrate/roughage ratio & $\% \mathrm{DM}^{*}$ & $32 / 68$ & $33 / 67$ & $42 / 58$ \\
\hline
\end{tabular}

$*$ The $\%$-share of concentrate over the $\%$-share of silage in total amount of dry matter in the diet.

Table 6. Decisions rules and value functions under a premium subsidy for heavy animals.

\begin{tabular}{llrrr}
\hline & & \multicolumn{3}{c}{ Silage price } \\
\cline { 3 - 5 } & & Low & Medium & High \\
\hline Carcass weight at slaughter & $\mathrm{kg}$ & 272 & 271 & 271 \\
Age & days & 488 & 481 & 474 \\
Value function & FIM & 15,687 & 14,526 & 11,617 \\
Premium subsidy & FIM & 400 & 500 & 800 \\
Concentrate/roughage ratio & $\%$ DM* & $26 / 74$ & $29 / 71$ & $33 / 67$ \\
\hline
\end{tabular}

* The $\%$-share of concentrate over the $\%$-share of silage in total amount of dry matter in the diet.

is determined so that it provides incentives to raise animals to the carcass weight of at least $270 \mathrm{~kg}$. The results suggest that the premium subsidy should be FIM 400 (€67) at the low silage price, FIM 500 (€84) at the medium silage price and FIM $800(€ 135)$ at the high silage price (Table 5). Thus, the premium subsidy granted for heavier animals should be FIM 200-600 (€34-€86) higher than it was in 2001. Similar effect could also be generated by a price premium of FIM 0.75-2.22 (€0.17-€0.32) per kilogram of meat granted only for carcasses heavier than 270 kilograms. These threshold levels of the premium subsidies and prices would, nevertheless, be inefficient in subsidizing farmer income because most of the premiums would be lost in extra feeding costs to increase carcass weights (Tables 5 and 6).

The premium subsidy will also have implications for optimal feeding ratios. It would increase the share of concentrates on farms having the low silage price but keep the feeding ratios practically unchanged on farms having the high silage price (Table 6).

\section{Results of sensitivity analysis}

The simulated $15 \%$ changes in the meat and calf prices do not change the optimal timing of slaughtering but they have large impacts on farmer returns. If the meat price decreases by $15 \%$ the value of the optimal value function decreases by $17 \%$. The decrease of $15 \%$ in calf price, on the other hand, increases the value of optimal value function by $9 \%$. These simulation results are reported in more detail in Appendix 2.

\section{Concluding remarks}

Estimated optimal cattle feeding and slaughtering indicate that the Agenda 2000 reform has significant effects on the beef sector and on farmer incentives to raise animals in a country like Finland with its high production costs. If the European common reform is not supplemented by any domestic programs it will weaken the 
Pihamaa, P. \& Pietola, K. Optimal beef cattle management in Finland

supply of beef. At decreased prices, it is not profitable to grow heavier animals and optimal carcass weights will be decreased by about $55 \mathrm{~kg}$. If the number of slaughtered bulls decreases from 192,700 in 1998 by $2 \%$ annually and the carcass weight decreases as predicted from $255 \mathrm{~kg}$ down to $200 \mathrm{~kg}$, the supply for beef is predicted to decrease by 13.6 million $\mathrm{kg}$, which accounts for $14.6 \%$ of the total beef supply in 1998 .

The predicted supply effect of the Agenda 2000 reform is large, because the subsidy payments dominate farmer decisions to choose most profitable timing of slaughtering. The reform will make these payments even more dominant than they were in 1998. It will also reschedule the subsidy payments earlier such that farmer incentives to rear heavy animals is significantly decreased.

The Agenda reform has also important implications for optimal feeding ratios. The general tendency is that concentrates are substituted for silage more than before the reform, because silage price is based on high domestic production costs but the price of concentrates follow decreased market prices. When silage is priced at average variable costs (medium price in the text), the amount of silage in the optimal feeding ratio is predicted to decrease by $12 \%$. The share of silage will be decreased in feeding by 9\%-points (from $76 \%$ to $67 \%$ ). The Agenda reform gives reason to be concerned about animal welfare, since it will alter the optimal diet apart from the ruminants' natural diet. Rich feeding ratios are expected to decrease ruminants welfare (Huhtanen 1998).

The Agenda reform is predicted to increase farmer returns because subsidies are increased and farmers will adjust feeding and the timing of slaughtering to the decreased prices. Nevertheless, if Agenda reform is supplemented by a domestic subsidy enhancing the supply of beef, this subsidy has negligible effects on farmer income. Raising heavier animals increases the production costs of beef. Thus the subsidy can be interpreted as a subsidy for consumers rather than an income subsidy for beef producers.

In summary, the results of this study support the foundations of Seppälä et al. (1999) indicating that Agenda reform increases farmer income and the share of concentrates in the optimal feeding ratios, but the optimal carcass weight decreases and hence the supply for domestic beef.

Acknowledgements. The authors thank two anonymous referees, professor Matti Ylätalo, agricultural economist AnnaMaija Heikkilä and docent Matti Ryhänen for their suggestions to improve earlier versions of this study.

\section{References}

Bellman, R. 1957. Dynamic Programming. New Jersey. $339 \mathrm{p}$.

Boland, M.A., Preckel, P.V. \& Schinckel, A.P. 1993. Optimal hog slaughter weights under alternative pricing systems. Journal of Agricultural and Applied Economics 25: 148-163.

EU 2000a. Commission Decision of 7 June 2000 amending Decision 95/196/EC on the long-term national aid scheme for agriculture in the northern regions of Finland (notified under document number C (2000) 1539). (Only the Finnish and Swedish texts are authentic).

EU 2000b. Commission Regulation (EC) No 2342/1999 of 28 October 1999 laying down detailed rules for the application of Council Regulation (EC) No 1254/ 1999 on the common organisation of the market in beef and veal as regards premium schemes.
Glen, J.J. 1983. A dynamic programming model for pig production. Journal of the Operational Research Society 34, 6: 511-519.

Huhtanen, P. 1998. Sonnia ei pidä kasvattaa sian rehulla. Lihatalous 1: 24-25.

Huirne, R.B.M., Van Beek, P., Hendriks, T.H.B. \& Dijkhuizen, A.A. 1993. Stochastic dynamic programming to support sow replacement decisions. European Journal of Operational Research 67: 161-171.

Maaseudun Tulevaisuus 1998. Lihakunnan veroton tuottajahinnasto. Maaseudun Tulevaisuus 1.8.1998.

MMM 1998. Yleiskirje Nro 1/98. Helsinki, Maa- ja metsätalousministeriö. Dnro 244/01/98.

MTTL 2000. Finnish Agriculture and Rural Industries 1999/2000. Agricultural Economics Research Institute. Publications 95a. $95 \mathrm{p}$.

Nissi, V. \& Pietola, K. 1999 Väkirehutason ja ruokinnan 
Vol. 11 (2002): 3-11.

jaksottamisen taloudellinen merkitys naudanlihantuotannossa. Abstract: Gains from utilizing compensatory growth characteristics of Ayrshire bulls. Agricultural Economics Research Institute. Research reports 237: 7-65.

Rinne, M., Manni, K. \& Huhtanen, P. 1998. Väkirehun ruokintastrategiat lihanaudoilla. Kotieläintieteen päivät 1998. Maaseutukeskusten liiton julkaisuja 924: 131-136.

Seppälä, R., Sipiläinen, T. \& Ryhänen, M. 1999. Agenda 2000 -ratkaisu ja eri tukiyhdistelmien vaikutus lihasonnin kasvatukseen ja optimiteurastuspainoon. Helsingin yliopiston taloustieteen laitos. Selvityksiä 7: 61-95.

TIKE 1999. Monthly Review of Agricultural Statistics 3. Information Centre of the Ministry of Agriculture and Forestry. Helsinki.

TIKE 2000a. Monthly Review of Agricultural Statistics 6.
Information Centre of the Ministry of Agriculture and Forestry. Helsinki.

TIKE 2000b. Monthly Review of Agricultural Statistics 3. Information Centre of the Ministry of Agriculture and Forestry. Helsinki.

TIKE 2000c. Yearbook of Farm Statistics 2000. Information Centre of the Ministry of Agriculture and Forestry. Helsinki.

TIKE 2000d. Balance Sheet for Food Commodities 1998 and 1999 (preliminary). Information Centre of the Ministry of Agriculture and Forestry. Helsinki.

TIKE 2001. Monthly Review of Agricultural Statistics 10. Information Centre of the Ministry of Agriculture and Forestry. Helsinki.

Van Arendonk, J.A.M. 1985. Studies on replacement policies in dairy cattle: 2 . Optimum policies and the influence of changes in production and prices. Livestock Production Science 13: 101-121.

\title{
SELOSTUS
}

\section{Politiikkamuutosten vaikutus lihanautojen optimaaliseen ruokintaan ja teurastuksen ajoitukseen}

\author{
Pekka Pihamaa ja Kyösti Pietola \\ MTT (Maa- ja elintarviketalouden tutkimuskeskus)
}

\begin{abstract}
Naudanlihan tuottajahintojen voimakkaasti alentuessa suomalaisen naudanlihan tuotantoa on ylläpidetty tukitoimenpitein, joilla tiettyyn ikään tai teuraspainoon kasvatetuista naudoista on maksettu viljelijälle palkkiota. Tukitoimenpiteistä huolimatta naudanlihan tuotanto on alentunut Suomessa EU-jäsenyysvuosien aikana huomattavasti, eikä kotimaisen lihan tarjonta ole enää 1990-luvun lopulla riittänyt kattamaan sen kysyntää. Uudet, koko EU:n kattavat maatalouspolitiikan uudistukset alentavat naudanlihan tuottajahintoja edelleen ja lisäävät viljelijöiden riippuvuutta eläinten pitoon sidottuihin tulotukiin. Etenkin korkeiden tuotantokustannusten Suomessa uudistus herättää tärkeitä kysymyksiä siitä, kyetäänkö järjestelmällä enää ylläpitämään riittävää kotimaisen naudanlihan tarjontaa, ja kuinka tehokkaita eläinten pitoaikoihin ja teuraspainoihin kytketyt tuet ovat viljelijän ja yhteiskunnan hyvinvoinnin kannalta.

Tässä tutkimuksessa selvitettiin lihasonnien optimaalisia ruokintatapoja ja teuraspainoja Agenda 2000 -uudistusta edeltäneillä ja sen jälkeen odotetuilla naudanlihan hinnoilla sekä sonnien pitoon kytke-
\end{abstract}

tyillä tuilla. Mallit optimoitiin kolmella eri säilörehun hinnalla, koska säilörehun hinnat vaihtelevat tilakohtaisesti. Naudan ruokinta ja teurastuksen ajoitus optimoitiin numeerisesti käyttämällä dynaamista ohjelmointia.

Ellei Agenda 2000 -uudistusta täydennetä kansallisilla naudanlihan tarjontaa vahvistavilla toimenpiteillä, sonnien optimaalinen teuraspaino alenee ja naudanlihan tarjonta heikkenee merkitsevästi.

Mikäli tavoitteena pidetään yli 270 kilon teuraspainoja, tulisi painavien sonnien teurastuksesta maksaa tukea yli 500 markkaa, kun vuonna 2001 vastaava tuki on 200 markkaa. Suuruudeltaan 400-800 markan tuki kannustaisi viljelijää kasvattamaan raskaita sonneja, mutta tuki kuluisi lähes kokonaan lisäkasvatuksen kustannuksiin. Tämän suuruinen tuki olisikin luonteeltaan ensisijaisesti kuluttajatukea, joka vahvistaisi kotimaisen naudanlihan tarjontaa, mutta se ei oleellisesti kasvattaisi viljelijän saamaa maataloustuloa. Vasta 800 markkaa ylittävältä osalta tuki olisi selkeästi suoraa tulotukea, josta pääosa jäisi viljelijälle. 
Appendix 1

\section{Growth function}

The exponential type Gompertz function is usually expressed as an equation between the animal age $(t)$ and weight $\left(x_{t}\right)$ :

$$
x_{t}=a \exp (-k \exp (-b t))
$$

where $a, b$ and $k$ are parameters. Parameters $a$ and $b$ are usually referred to as an adult weight and a maturating ratio of the animal. A more convenient form for estimation is obtained by differentiating the levels form Gompertz function with respect to age of animal. This differentiated form of (A1.1) is:

$$
x_{t+1}=x_{t}\left(c-b \ln x_{t}\right)+u_{t}
$$

where $c=1+b \ln a$, and $u_{t}$ is an error. The estimation results indicate that the parameters $b$ and $c$ differ significantly from zero in both feeding groups (Table A1.1).

Table A1.1. Parameter estimates in the growth function (A1.2) by feeding groups (t-values in parentheses).

\begin{tabular}{lcccc}
\hline & & Parameter & & R squared \\
& $\mathrm{a}$ & $\mathrm{b}$ & $\mathrm{c}$ & \\
\hline Feeding group 1 & 717.3 & 0.135 & 1.89 & \multirow{2}{*}{0.996} \\
& & $(19.9)$ & $(46.4)$ & \\
Feeding group 2 & \multirow{2}{*}{713.6} & 0.143 & 1.94 & 0.997 \\
& & $(21.5)$ & $(48.7)$ & \\
\hline
\end{tabular}

Serial correlation in the error $u_{t}$ was tested by estimating an auxiliary regression

$$
u_{t}=\phi u_{t-1}+v_{t}
$$

where $v_{\mathrm{t}}$ is an error and $\phi$ is a parameter. The results suggest that $\phi$ does not significantly differ from zero, which implies that serial correlation is insignificant (Table A1.2.).

Heteroskedastic error was tested for by estimating an auxiliary regression of the from

$$
\ln \left(u_{t}^{2}\right)=\gamma_{0}+\gamma_{1} x_{t}+\varepsilon_{t}
$$

where $u_{t}^{2}=$ is the squared error of equation (A1.2), $\varepsilon_{t}$ is an error, and $\gamma$ are parameters. The results suggest that the error is heteroskedastic in feeding group 1 (i.e. $\gamma_{1} \neq 0$ ) and the parameter estimates are no longer efficient. Therefore, the growth function (A1.2) was re-estimated in feeding group 1 using Generalized Least Squares (GLS) technique such that heteroskedasticity of the form reported in Table (A1.2) was corrected for. Nevertheless, the GLS results given in Table (A1.3) suggest that correcting for heteroskedasticity did not, in practice, change the parameter estimates from those 
Appendix 1

obtained by OLS. Therefore, the original OLS estimates reported in Table A1.1 were used for both feeding groups in the DP algorithm. The fitted growth functions and the observed data points are plotted in Figures A1.1 and A1.2.

Table A1.2. Parameter estimates and their t-values (in parentheses) in (A1.3) and (A1.4).

\begin{tabular}{lccc}
\hline & Serial correlation (A1.3) & \multicolumn{2}{c}{ Heteroskedasticity (A1.4) } \\
& $\phi$ & $\gamma_{0}$ & $\gamma_{1}$ \\
\hline \multirow{2}{*}{ Feeding group 1 } & 0.0348 & 2.12 & 0.00257 \\
\multirow{2}{*}{ Feeding group 2 } & $(0.397)$ & $(4.70)$ & $(1.97)$ \\
& 0.105 & 2.22 & 0.00154 \\
& $(1.12)$ & $(4.01)$ & $(0.961)$ \\
\hline
\end{tabular}

Table A1.3. GLS estimates for the parameter in the growth function for feeding group 1 ( $t$-values in parentheses).

\begin{tabular}{lcccc}
\hline & \multicolumn{3}{c}{ Parameter } & R squared \\
& $\mathrm{a}$ & $\mathrm{b}$ & $\mathrm{c}$ & \\
\hline Feeding group 1 & 709.9 & $\begin{array}{c}0.138 \\
(22.5)\end{array}$ & $\begin{array}{c}1.90 \\
(52.6)\end{array}$ & 0.991 \\
\hline
\end{tabular}

\section{Demand of silage}

The demand of silage was estimated in

(A1.5) $\quad y=a+b^{*} \ln (x)$

where $y$ is daily demand of silage measured in dry matter and $a$ and $b$ are parameters. The fitted functions and the observed data points are plotted in Figures A1.3. and A1.4.

Table A1.4. Parameter estimates in the silage demand functions by feeding groups (t-values in parenthesis).

\begin{tabular}{lcc}
\hline & \multicolumn{2}{c}{ Parameter } \\
& $\mathrm{a}$ & $\mathrm{b}$ \\
\hline \multirow{2}{*}{ Feeding group 1 } & -12.0 & 3.01 \\
& $(-22.8)$ & $(-32.4)$ \\
Feeding group 2 & -10.5 & 2.55 \\
& $(-19.7)$ & $(-27.1)$ \\
\hline
\end{tabular}




\section{Appendix 1}

\section{Demand of barley}

The demand of barley was estimated in

$$
\text { (A1.6) } \quad \mathrm{y}=\mathrm{ax}^{0.6}
$$

where $y$ is daily demand of barley measured in dry matter and $a=$ parameter. The fitted functions and the observed data points are plotted in Figures A1.5 and A1.6.

Table A1.5. Parameter estimates in barley demand function by feeding groups ( $\mathrm{t}$-values in parenthesis).

\begin{tabular}{lcc}
\hline & $\begin{array}{c}\text { Parameter } \\
\mathrm{a}\end{array}$ & $\mathrm{R}$ squared \\
\hline Feeding group 1 & $\begin{array}{c}0.0487 \\
(239.1)\end{array}$ & \multirow{2}{*}{0.971} \\
& $\begin{array}{c}0.0942 \\
\text { Feeding group 2 }\end{array}$ & \multirow{2}{*}{0.900} \\
\hline
\end{tabular}




\section{AGRICULTURAL AND FOOD SCIENCE IN FINLAND}

Appendix 1

Live weight, $\mathrm{kg}$

Growth of animals in 1 st group

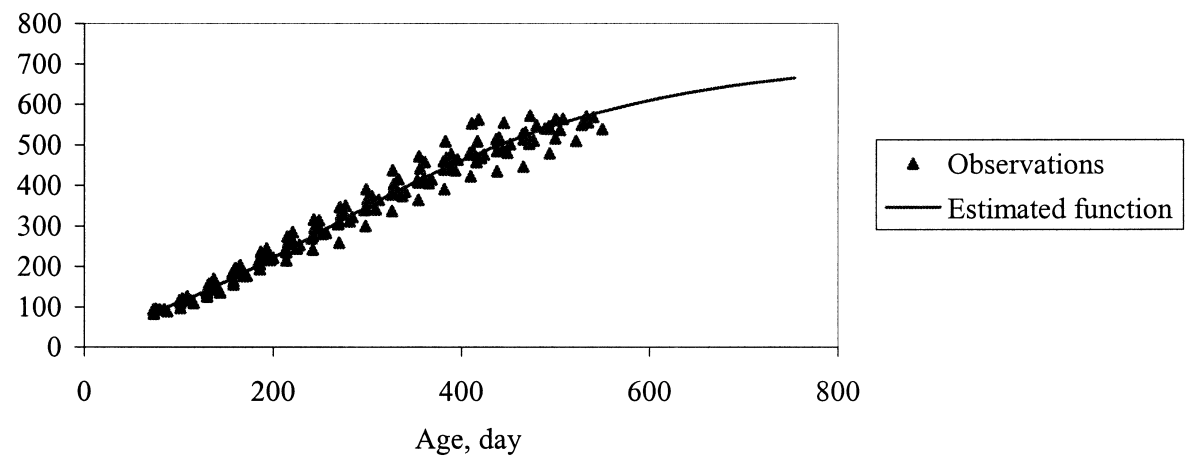

Fig. A1.1. Animal growth in group 1.

Live weight, $\mathrm{kg}$

Growth of animals in 2 nd group

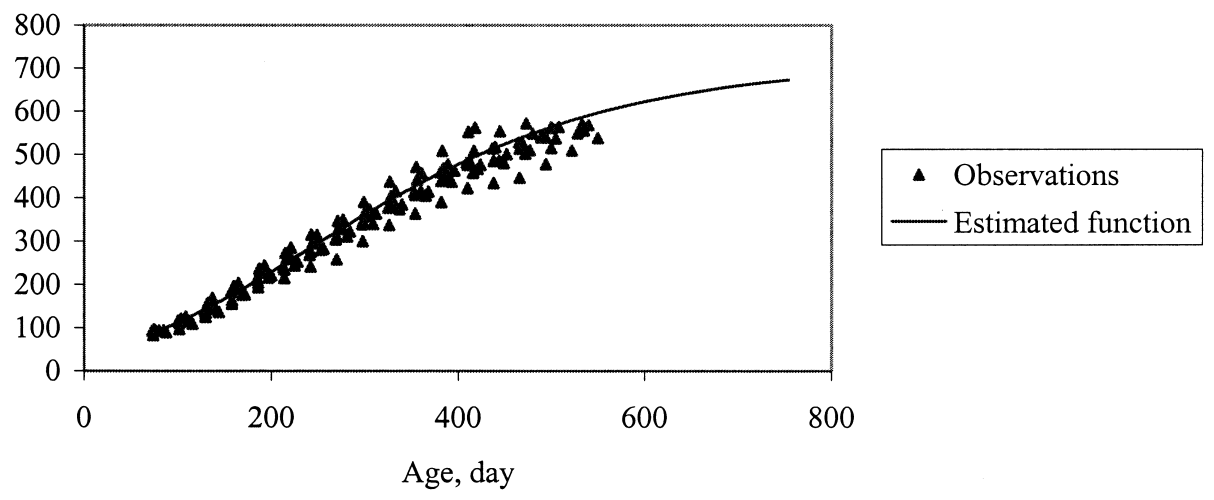

Fig. A1.2. Animal growth in group 2.

Silage, kg DM / day

\section{Silage demand of group 1}

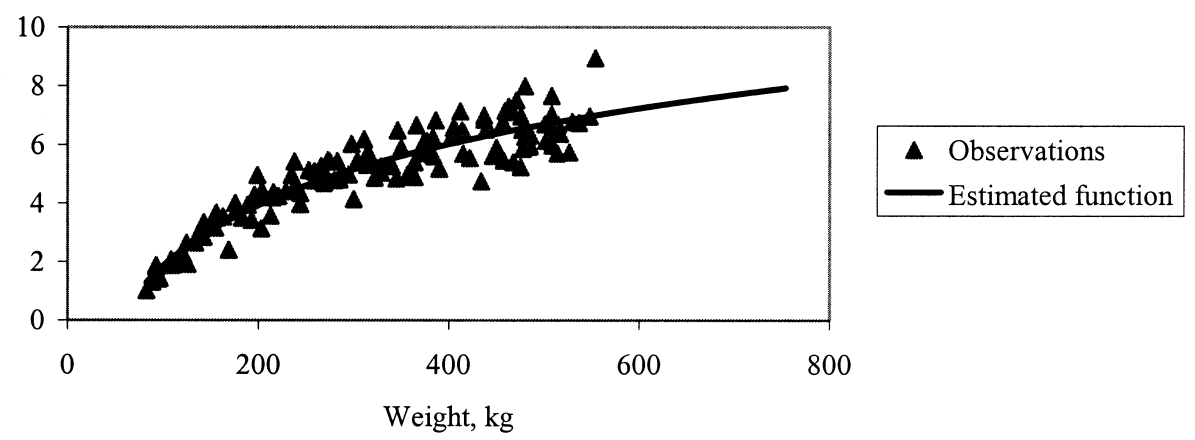

Fig. A1.3. The demand of silage in group 1. 


\section{Appendix 1}

Silage kg DM/day

Silage demand of group 2

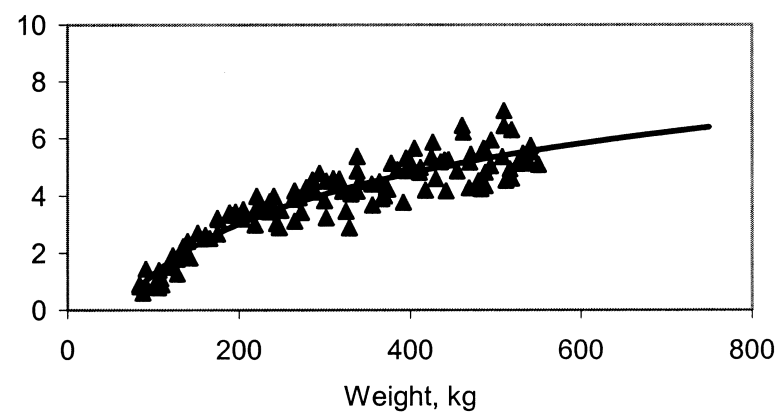

\ Data

- Estimated function

Fig. A1.4. The demand of silage in group 2.

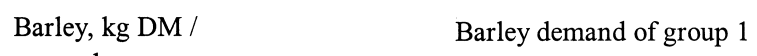
day

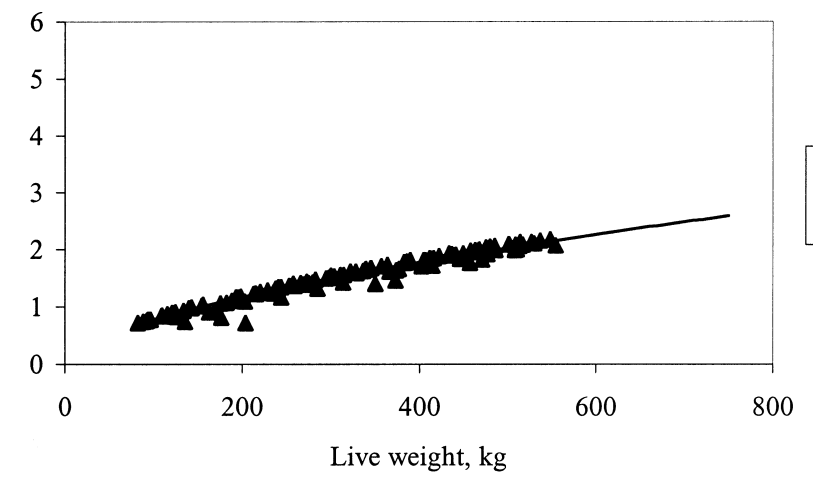

\ Observations

Estimated function

Fig. A1.5. Demand of barley in group 1.

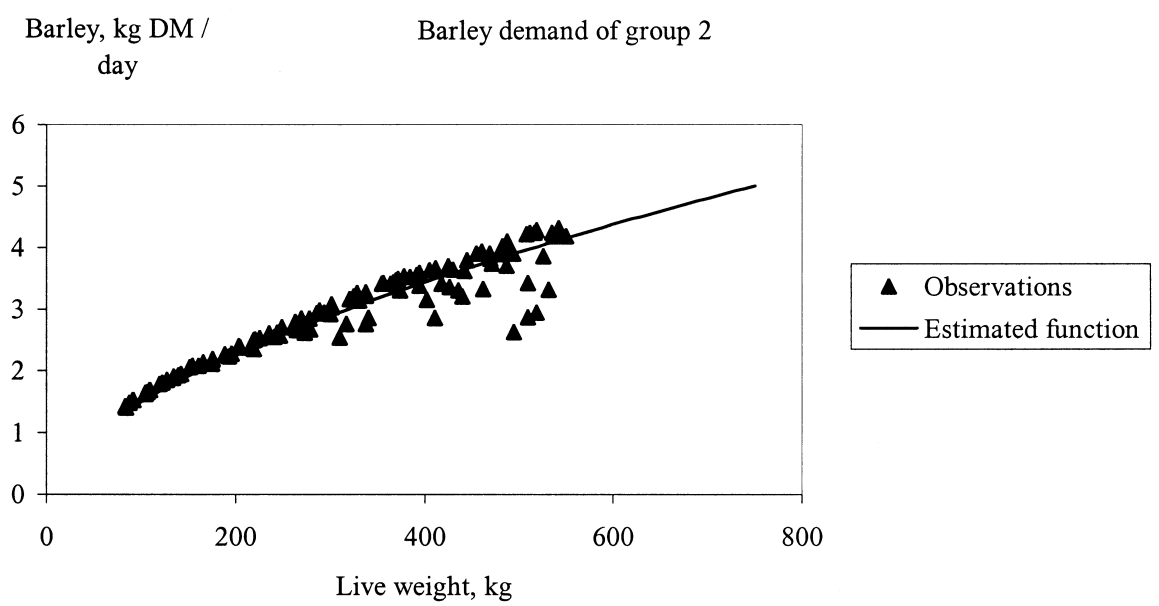

Fig. A1.6. Demand of barley in group 2. 


\section{Appendix 2}

Results of sensitivity analysis

Table A2.1. Optimal decision rules and value functions at 2002 prices and subsidies. Price of calf is a variable factor and silage fixed at the medium price.

\begin{tabular}{lccrr}
\hline & \multicolumn{4}{c}{ Calf price } \\
& unit & Low (-15\%) & Medium & High $(+15 \%)$ \\
\hline price of calf & FIM & 1,389 & 1,208 & 1,389 \\
Liveweight & $\mathrm{kg}$ & 391 & 390 & 390 \\
Carcass weight & $\mathrm{kg}$ & 192 & 191 & 191 \\
Age & days & 327 & 327 & 327 \\
Age & months & 10.9 & 10.9 & 10.9 \\
Value function & FIM & 15,541 & 14,289 & 13,070 \\
Concentrate / & & & & \\
roughage ratio & $\% \mathrm{DM}^{*}$ & $34 / 66$ & $33 / 67$ & $33 / 67$ \\
Change in value & & & & \\
function & $\%$ & $9 \%$ & $0 \%$ & $-9 \%$ \\
\hline
\end{tabular}

* The \%-share of concentrate over the \%-share of silage in total amount of dry matter in the diet

Table A2.2. Three alternative meat prices simulated.

\begin{tabular}{ccrrr}
\hline & change & $\begin{array}{c}\text { Low } \\
(-15 \%)\end{array}$ & Medium & \multicolumn{1}{c}{$\begin{array}{c}\text { High } \\
(+15 \%)\end{array}$} \\
\hline Carcass weight & & & & \\
Under 189 kg & FIM $/ \mathrm{kg}$ & 10.03 & 11.80 & 13.57 \\
$190-229 \mathrm{~kg}$ & FIM $/ \mathrm{kg}$ & 10.54 & 12.40 & 14.26 \\
$230-259 \mathrm{~kg}$ & FIM $/ \mathrm{kg}$ & 11.22 & 13.20 & 15.18 \\
$260-299 \mathrm{~kg}$ & FIM $/ \mathrm{kg}$ & 11.90 & 14.00 & 16.10 \\
Over 300 kg & FIM/kg & 12.33 & 14.50 & 16.68 \\
\hline
\end{tabular}

Table A2.3. Optimal decision rules and value functions at 2002 prices and subsidies. When alternative meat prices are simulated the price of silage and the price of calf are fixed at "medium".

\begin{tabular}{lcrrr}
\hline & \multicolumn{3}{c}{ Meat price } \\
\multicolumn{1}{c}{ unit } & Low (-15\%) & Medium & High (+15\%) \\
\hline Carcass weight & $\mathrm{kg}$ & 191 & 191 & 192 \\
Age & months & 10.9 & 10.9 & 10.9 \\
$\begin{array}{l}\text { Value function } \\
\text { Concentrate / }\end{array}$ & FIM & 11,891 & 14,289 & 16,692 \\
$\begin{array}{l}\text { roughage ratio } \\
\begin{array}{l}\text { Change in value } \\
\text { function }\end{array}\end{array}$ & $\% \mathrm{DM}^{*}$ & $33 / 67$ & $33 / 67$ & $34 / 66$ \\
\hline
\end{tabular}

* The $\%$-share of concentrate over the $\%$-share of silage in total amount of dry matter in the diet 